\title{
The assessment of the of the usefulness of a Rapid Compression Machine in optical research on the injection and combustion processes of liquid fuels
}

\begin{abstract}
In the paper the possibilities of A Rapid Compression Machine in the investigation of the fundamental processes in IC engines have been presented. The test-stand design, principles of its control and basic operational features have been discussed and compared with the parameters of the test facilities of similar type currently in use worldwide. A short evaluation has been performed of its functionality and possibilities of application in the research on thermodynamics of injection and combustion processes. The evaluation pointed to the possibility of variation of the parameters and variables in the RCM. The main parameters and operational indexes of the Test-stand have been presented along with some examples of the achieved results from the investigations of engine internal processes.
\end{abstract}

Key words: combustion of liquid fuels, Rapid Compression Machine, optical investigations

\section{Ocena przydatności Maszyny Pojedynczego Cyklu do optycznych badań procesu wtrysku i spalania paliw ciekłych}

\begin{abstract}
W artykule przedstawiono możliwości wykorzystania Maszyny Pojedynczego Cyklu do badania podstawowych procesów silnikowych. Omówiono budowę stanowiska, zasady sterowania jego praca oraz podstawowe cechy użytkowe, które porównano z innymi urządzeniami tego typu stosowanymi w badaniach światowych. Przeprowadzono krótka ocenę jego funkcjonalności i możliwości prowadzenia badań w zakresie termodynamiki procesów wtrysku i spalania $z$ wykorzystaniem metod indykatorowych oraz badań optycznych wskazujac na wariantowania cech konstrukcyjnych oraz parametrów i zmiennych sterujących procesami silnikowymi. Zaprezentowano warunki pracy urządzenia i przedstawiono przyktadowe wyniki badań i analiz procesów wewnątrzsilnikowych.
\end{abstract}

Słowa kluczowe: spalanie paliw cieklych, Maszyna Pojedynczego Cyklu, badania optyczne

\section{Introduction}

Modern advanced engine research in the area of injection, atomization and combustion of liquid fuels is frequently conducted with the help of optical methods on research engines (transparent engines or endoscopic engines), rapid compression machines and sometimes pressure chambers of constant volume. The use of research engines is difficult because it requires the system to reach an appropriate thermodynamic state before the actual investigations can be initiated. This is a serious issue that the researchers have to overcome. During the operation of these machines, particularly at start-up, there is an intense reduction of transparence of the optical access point to the working area right after a few cycles of operation. The observations are particularly difficult under heavy engine load.

The here listed issues as well as high costs of such investigations shift the interest towards machines in which a single working cycle is used. These machines, due to a lack of regular crankshaft mechanism do not operate in repeated cycles but realize a single one only. It is possible to obtain appropriate operating conditions without the necessity of engine start-up thanks to a variety of solutions for parameter conditioning of the individual engine subsystems (air intake, fuel dose level, piston cylinder temperature, piston travel

\section{Wstęp}

Współczesne zaawansowane badania silnikowe w zakresie procesów wtrysku, rozpylenia i spalania paliw ciekłych prowadzone są często metodami optycznymi z zastosowaniem silników badawczych (tzw. transparentnych lub z dostępem endoskopowym), maszyn pojedynczego cyklu, czasem także komór ciśnieniowych o stałej objętości. Wykorzystywanie silników badawczych jest utrudnione, gdyż wymaga wcześniejszego osiągania właściwego stanu termodynamicznego układu przed prowadzeniem badań właściwych i napotyka na znaczne trudności techniczne. W czasie ich pracy, szczególnie w warunkach rozruchu, następuje intensywne zmniejszenie przezroczystości dojścia optycznego do przestrzeni roboczej już po kilku pierwszych cyklach pracy. Szczególnie utrudnione są obserwacje w warunkach dużego obciążenia silnika.

Wspomniane problemy, a także znaczne koszty takich badań, powodują, że coraz większe zainteresowanie dotyczy maszyn, w których wykorzystuje się pojedynczy proces roboczy. Maszyny te ze względu na brak typowego mechanizmu korbowego nie pracują w sposób cykliczny, a realizują jedynie pojedynczy cykl roboczy. Możliwe jest w nich uzyskiwanie właściwych warunków pracy bez ich uruchamiania dzięki wykorzystaniu szeregu układów do 
velocity - converted into engine speed). The performance of the recording of a single quick changing process requires the use of measurement and filming devices operating at very high frequencies reaching several kilohertz.

\section{System mechanics}

A Rapid Compression Machine (RCM) used in Poznan University of Technology allows basic research within a single working cycle of a combustion engine, particularly in relation to the process of fuel injection, charge motion, ignition and combustion. The RCM is composed of a cylinder where a piston is placed built in such a way that optical access is available to the combustion chamber from the piston crown (Fig. 1); there is also an easy option ensuring optical access from the cylinder head $[2,14,15]$. The first configuration allows using the whole available cylinder head space to enable reflecting the typical injector and spark plug location.

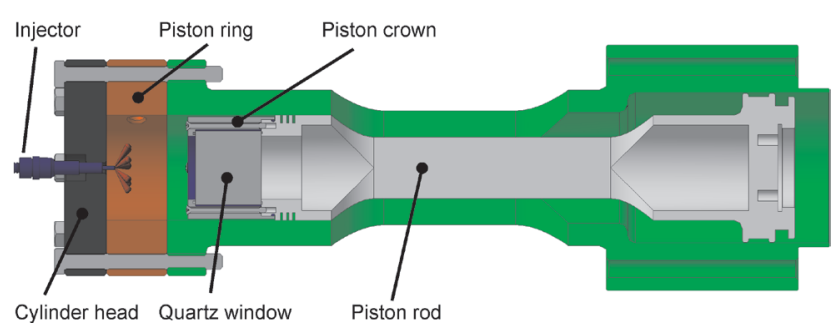

Fig. 1. Schematics of a Rapid Compression Machine with optical access to the combustion chamber

Rys. 1. Schemat Maszyny Pojedynczego Cyklu z dostepem optycznym do komory spalania

The lack of the crankshaft mechanism requires a pneumatic solution that forces the movement of the piston. For the control of the piston motion (compression stroke) air of controlled pressure is used up to $8 \mathrm{MPa}$ supplied under the piston. The variable pressure of the control air and the intensity of its supply allow realization of different piston velocities thus reflecting different engine speeds. This same air plays a role of a damper when the piston moves towards bottom dead center due to the combustion in the cylinder. The adjustment of the air valve allows a variety of piston travel values hence also the geometrical compression ratio.

The functions of intake and exhaust valves are taken by electromagnetic valves that supply air of maximum pressure of $4 \mathrm{MPa}$, which enables a post injection of air at any piston position during the compression stroke. It is possible to use two intake valves that can force air swirl of any intensity (compare [2]). Such an option is unavailable in a traditional combustion engine with a conventional timing system. The exhaust of the gases is realized by an electromagnetic valve and the system is connected to an exhaust gas extraction system from a single combustion cycle. The technical parameters of a rapid compression machine have been shown in Table 1, and the view of the machine in Fig. 2.

The machine used in Poznan University of Technology reflects the state of current worldwide research quality. Similar devices used for basic injection and combustion processes come in a variety of configurations as has been shown in Table 2. kondycjonowania parametrów poszczególnych systemów (np. dolotu powietrza, zadanej dawki paliwa, temperatury układu tłokowo-cylindrowego, prędkości przesuwu tłoka - przeliczonej na prędkość obrotową silnika). Przeprowadzenie rejestracji pojedynczego szybkozmiennego procesu wymaga jednak zastosowania układów do pomiarów i filmowania pracujących z bardzo dużymi częstotliwościami sięgającymi ponad kilkunastu kiloherzów.

\section{Mechanika pracy układu}

Maszyna Pojedynczego Cyklu (Rapid Compression Machine $R C M$ ) stosowana w Politechnice Poznańskiej pozwala na badania typu podstawowego w zakresie pojedynczego cyklu roboczego silnika spalinowego, szczególnie w odniesieniu do procesów wtrysku paliwa, ruchu ładunku, zapłonu i spalania. Zbudowana jest ona z cylindra roboczego, w którym umieszczono tłok wykonany w ten sposób, aby możliwy był dostęp optyczny do komory spalania od denka tłoka (rys. 1); łatwe jest również zastosowanie wariantu, w którym dostęp optyczny uzyskiwany jest także od strony głowicy $[2,14,15]$. Ta pierwsza konfiguracja pozwala na wykorzystanie całej dostępnej przestrzeni głowicy silnika, aby możliwe było odwzorowanie typowego umieszczenia wtryskiwaczy i świecy zapłonowej.

Brak mechanizmu korbowego wymagał wyposażenia maszyny w pneumatyczny układ wymuszający ruch tłoka. Do sterowania ruchem tłoka (suw sprężania) wykorzystuje się powietrze o regulowanym ciśnieniu do $8 \mathrm{MPa}$ dostarczane do przestrzeni podtłokowej. Zmienne ciśnienie powietrza sterującego i intensywność jego dostarczania pozwala na realizację różnej prędkości ruchu tłoka, a tym samym na odwzorowanie różnej prędkości obrotowej silnika spalinowego. To samo powietrze pełni funkcję amortyzatora przy ruchu tłoka w kierunku DMP wywołanym spalaniem w przestrzeni roboczej cylindra. Nastawa zaworu powietrza sterującego pozwala na uzyskiwanie różnej wartości skoku roboczego tłoka, a więc także geometrycznego stopnia sprężania.

Funkcję zaworów dolotowych i wylotowych realizują zawory elektromagnetyczne dostarczające powietrze o maksymalnym ciśnieniu do $4 \mathrm{MPa}$, co pozwala na dotrysk powietrza w dowolnym położeniu tłoka podczas sprężania. Możliwe jest umieszczenie dwóch zaworów dolotowych mogących realizować wymuszenie zawirowania powietrza dolotowego o różnej intensywności (por. [2]). Opcja taka nie występuje w tradycyjnym silniku spalinowym z konwencjonalnym napędem rozrządu. Wylot spalin realizowany jest również przez zawór elektromagnetyczny połączony z układem poboru spalin z pojedynczego cyklu spalania. Parametry techniczne maszyny pojedynczego cyklu przedstawiono w tab. 1, a jej widok na rys. 2.

Maszyna stosowana w badaniach w Politechnice Poznańskiej odzwierciedla stan obecnych badań światowych. Podobne urządzenia służące do badań podstawowych procesów wtrysku i spalania występują w różnych konfiguracjach, co przedstawiono w tab. 2.

Pracą RCM steruje urządzenie komputerowe - tzw. sequencer, generujący poszczególne sygnały do elementów wykonawczych (zaworów elektromagnetycznych), 
Table 1. Technical data of the Rapid Compression Machine used at Poznan University of Technology

Tablica 1. Dane techniczne wykorzystywanej Maszyny Pojedynczego Cyklu

\begin{tabular}{|c|c|}
\hline Quantity/wielkość & Value/wartość \\
\hline Stroke/skok tloka & $81 \mathrm{~mm}$ \\
\hline Bore/średnica cylindra & $80 \mathrm{~mm}$ \\
\hline Cylinder volume/objętość cylindra & $407 \mathrm{~cm}^{3}$ \\
\hline Combustion chamber volume/objętość komory sprężania & $\mathrm{SI} / Z I-66.5 \mathrm{~cm}^{3} ; \mathrm{CI} / Z S-46.6 \mathrm{~cm}^{3}$ \\
\hline Air feed/sposób dostarczenia powietrza & $\begin{array}{l}\text { Electromagnetic valves, forced swirl/zawory elektromagnetyczne, wymuszenie } \\
\text { zawirowania powietrza }\end{array}$ \\
\hline Forced piston motion/sposób wymuszenia ruchu ttoka & Pneumatic/pneumatyczny \\
\hline $\begin{array}{l}\text { Geometrical compression ratio [-]/geometryczny stopień } \\
\text { sprężania }[-]\end{array}$ & $\mathrm{SI} / Z I-\min .6 .8 ; \mathrm{CI} / Z S-\min .11$ \\
\hline Actual compression ratio [-]/rzeczywisty stopień sprężania [-] & $\mathrm{SI} / Z I-6.8-14 ; \mathrm{CI} / Z S-11-20$ \\
\hline Compression/ciśnienie sprężania & $\mathrm{SI} / Z I-0.85-2.0 \mathrm{MPa} ; \mathrm{CI} / Z S-3.0-4.5 \mathrm{MPa}$ \\
\hline Ignition/zaplon & $\begin{array}{l}\text { SI - spark plug; CI- self ignition, possible glow plug }\left(1250^{\circ} \mathrm{C}\right) / Z I-\text { świeca zapto- } \\
\text { nowa; ZS - samozapton, ewentualnie świeca żarowa }\left(1250^{\circ} \mathrm{C}\right)\end{array}$ \\
\hline Type of combustion chamber/typ komory spalania & $\begin{array}{l}\text { SI }- \text { hemispherical chamber + chamber in the piston; } \mathrm{CI}-\text { chamber in the piston/ } \\
Z I-\text { komora pótkulista }+ \text { komora } w \text { tloku; } Z S-\text { komora } w \text { toku }\end{array}$ \\
\hline Piston deceleration/sposób hamowania ttoka & Pneumatic/pneumatyczny \\
\hline Piston velocity/prędkość ruchu tłoka & $\begin{array}{l}30-70 \mathrm{~m} / \mathrm{s} \text { depending on the pressure under the piston } / 30-70 \mathrm{~m} / \mathrm{s} \text { w zależności } \\
\text { od wartości ciśnienia powietrza pod tlokiem }\end{array}$ \\
\hline Piston tightness/uszczelnienie ttoka & Piston rings, PTFE seals/pierścienie ttokowe, uszczelnienie teflonowe \\
\hline Optical access/dostęp optyczny & $\begin{array}{l}\text { Quartz glass } \phi 48 \times 50 \mathrm{~mm} \text { placed under the combustion chamber in the piston, } \\
\text { possible placement in the cylinder head/szkto kwarcowe } \phi 48 \times 50 \text { mm umieszczone } \\
\text { od dotu komory spalania w ttoku, ewentualnie także w glowicy }\end{array}$ \\
\hline Injection/realizacja wtrysku & $\begin{array}{l}\text { SI - MPI injection type, direct multiple; } \mathrm{CI} \text { - direct CR, multiple/ZI - wtrysk typu } \\
\text { MPI, bezpośredni, wielofazowy; } Z S \text { - bezpośredni CR, wielofazowy }\end{array}$ \\
\hline Fuel injection pressure/ciśnienie wtrysku paliwa & $\begin{array}{l}\text { Adjustable: } \mathrm{SI}-5-30 \mathrm{MPa} \text {; CI - 30-140 MPa/regulowane: } Z I-5-30 \mathrm{MPa} \text {; } \\
Z S-30-140 \mathrm{MPa}\end{array}$ \\
\hline Combustion/realizacja spalania & $\begin{array}{l}\text { SI - homogenous mixtures, stratified/ } \\
\text { ZI - mieszanki homogeniczne, uwarstwione }\end{array}$ \\
\hline
\end{tabular}

a)

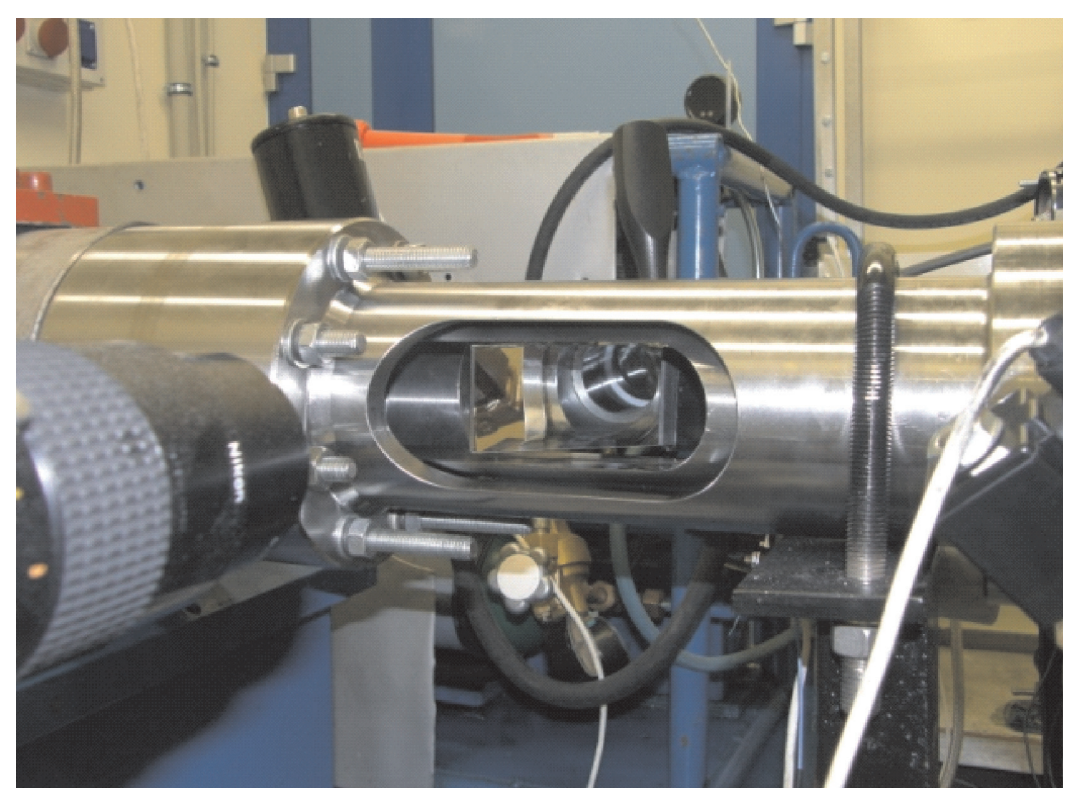

b)

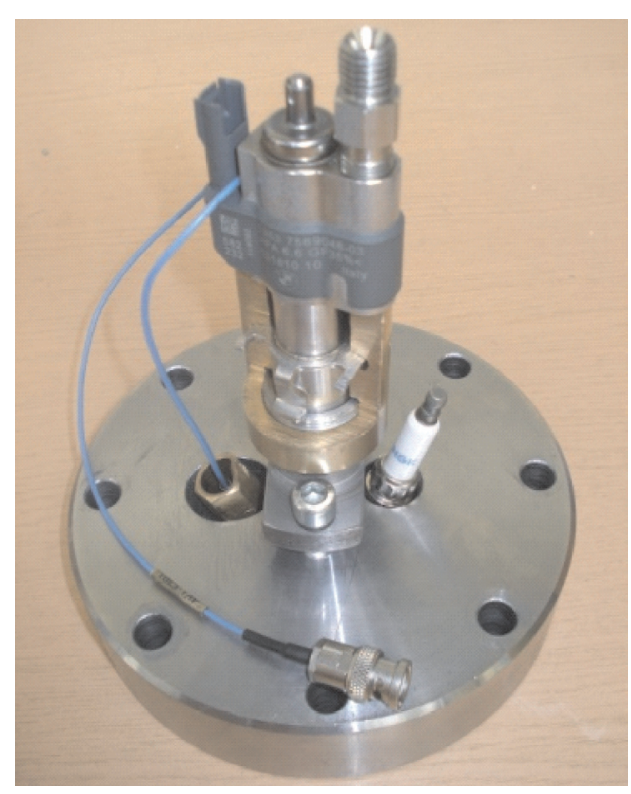

Fig. 2. Rapid Compression Machine: a) optical access to the combustion chamber, b) cylinder head with the fuel injection system and a combustion pressure sensor

Rys. 2. Maszyna Pojedynczego Cyklu: a) dostęp optyczny do komory spalania, b) głowica wraz z układem wytrysku benzyny oraz czujnikiem ciśnienia spalania 
Table 2. The comparison of the configuration of the Rapid Compression Machines (based on [5])

Tablica 2. Porównanie konfiguracji Maszyn Pojedynczego Cyklu (opr. na podst. [5])

\begin{tabular}{|c|c|c|c|c|c|c|c|}
\hline & & 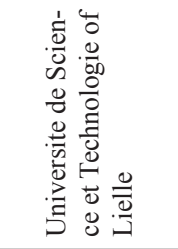 & 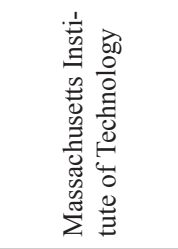 & 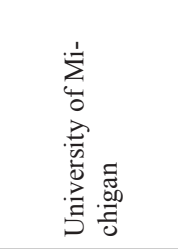 & 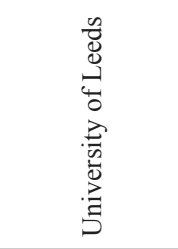 & 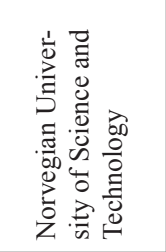 & 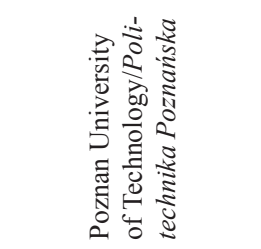 \\
\hline \multirow{3}{*}{ 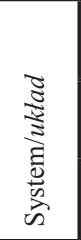 } & $\begin{array}{l}\text { Compressing piston/ttok } \\
\text { sprężający }\end{array}$ & Double $/ d w a$ & Single/jeden & Single/jeden & Single/jeden & Single/jeden & Single/jeden \\
\hline & $\begin{array}{l}\text { Forced acceleration/wymusze- } \\
\text { nie przyspieszenia }\end{array}$ & $\begin{array}{c}\text { Pneumatic/ } \\
\text { pneumatyczny }\end{array}$ & $\begin{array}{c}\text { Pneumatic/ } \\
\text { pneumatyczny }\end{array}$ & $\begin{array}{c}\text { Pneumatic/ } \\
\text { pneumatyczny }\end{array}$ & $\begin{array}{c}\text { Pneumatic/ } \\
\text { pneumatyczny }\end{array}$ & $\begin{array}{c}\text { Hydraulic/ } \\
\text { hydrauliczny }\end{array}$ & $\begin{array}{c}\text { Pneumatic/ } \\
\text { pneumatyczny }\end{array}$ \\
\hline & Deceleration/hamowanie & N.A./brak & $\begin{array}{l}\text { Hydraulic/ } \\
\text { hydrauliczny }\end{array}$ & N.A./brak & $\begin{array}{c}\text { Hydraulic/ } \\
\text { hydrauliczny }\end{array}$ & $\begin{array}{l}\text { Hydraulic/ } \\
\text { hydrauliczny }\end{array}$ & $\begin{array}{c}\text { Pneumatic/ } \\
\text { pneumatyczny }\end{array}$ \\
\hline \multirow{3}{*}{ 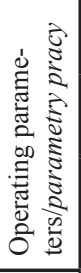 } & $\begin{array}{l}\text { Max compression ratio/max } \\
\text { stopień sprężania } \\
\end{array}$ & 10 & 19 & 37 & 11 & 9,5 & 20 \\
\hline & $\begin{array}{l}\text { Compression time }[\mathrm{ms}] / \mathrm{czas} \\
\text { sprężania [ms] }\end{array}$ & 60 & 30 & 70 & 22 & 20 & 30 \\
\hline & $\begin{array}{l}\text { Max compression pressure } \\
{[\mathrm{MPa}] / \text { max ciśnienie spręża- }} \\
\text { nia }[\mathrm{MPa}]\end{array}$ & 1.7 & 7 & 2 & 0.75 & 7 & 5 \\
\hline \multirow{4}{*}{ 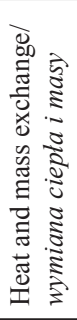 } & $\begin{array}{l}\text { Max wall temp. }[\mathrm{K}] / \max \\
\text { temp. ścianek }[K]\end{array}$ & 360 & $\begin{array}{c}\text { Heated/ } \\
\text { podgrzewanie }\end{array}$ & No data/b.d. & No data/b.d. & 393 & 423 \\
\hline & $\begin{array}{l}\text { Max charge temp. }[\mathrm{K}] / \max \\
\text { temp. tadunku }[\mathrm{K}]\end{array}$ & 360 & $\begin{array}{c}\text { Heated/ } \\
\text { podgrzewanie }\end{array}$ & No data/b.d. & No data/b.d. & 393 & 323 \\
\hline & $\begin{array}{l}\text { Turbulization of the charge/ } \\
\text { turbulizacja tadunku }\end{array}$ & No data/b.d. & No data/b.d. & No data/b.d. & No data/b.d. & No data/b.d. & $\begin{array}{l}\text { Forced, adjustable/wy- } \\
\text { muszone, regulowane }\end{array}$ \\
\hline & $\begin{array}{l}\text { Piston aerodynamics/aerody- } \\
\text { namika ttoka }\end{array}$ & $\begin{array}{c}\text { Basic/ } \\
\text { podstawowy }\end{array}$ & $\begin{array}{l}\text { Optimum/ } \\
\text { optymalny }\end{array}$ & $\begin{array}{l}\text { Optimum/ } \\
\text { optymalny }\end{array}$ & $\begin{array}{c}\text { Basic/ } \\
\text { podstawowy }\end{array}$ & $\begin{array}{c}\text { Basic/ } \\
\text { podstawowy }\end{array}$ & $\begin{array}{l}\text { Optimum/ } \\
\text { optymalny }\end{array}$ \\
\hline \multirow{4}{*}{ 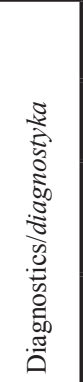 } & $\begin{array}{l}\text { Optical access/dostepp } \\
\text { optyczny }\end{array}$ & Bottom/dót & N.A./brak & $\begin{array}{l}\text { Top/bottom/ } \\
\text { góra/dót }\end{array}$ & Bottom/dót & Bottom/dót & $\begin{array}{l}\text { Top/bottom/ } \\
\text { góra/dót }\end{array}$ \\
\hline & $\begin{array}{l}\text { Pressure measurement/pomiar } \\
\text { ciśnienia }\end{array}$ & Yes/tak & Yes/tak & Yes/tak & Yes/tak & Yes/tak & Yes/tak \\
\hline & $\begin{array}{l}\text { Temperature reading/odczyt } \\
\text { temperatury }\end{array}$ & $\begin{array}{l}\text { Indirect/ } \\
\text { pośredni }\end{array}$ & No data/b.d. & $\begin{array}{l}\text { Thermoco- } \\
\text { uple/ } \\
\text { termopara }\end{array}$ & $\begin{array}{l}\text { Rayleigh ra- } \\
\text { diation/prom. } \\
\text { Rayleigha }\end{array}$ & No data/b.d. & $\begin{array}{l}\text { Bicolor method/meto- } \\
\text { da dwubarwowa }\end{array}$ \\
\hline & $\begin{array}{l}\text { Charge chemical composi- } \\
\text { tion/ } \\
\text { sktad chemiczny tadunku }\end{array}$ & $\mathrm{FID} / F I D$ & No data/b.d. & $\begin{array}{l}\text { OH Absorp- } \\
\text { tion/absorpcja } \\
\text { OH }\end{array}$ & $\begin{array}{l}\text { Spectrometer/ } \\
\text { spektrometr }\end{array}$ & No data/b.d. & $\begin{array}{l}\text { *) } \mathrm{OH}, \mathrm{CH} \text { absorption/ } \\
\text { Absorpcja }{ }^{*} \mathrm{OH}, \mathrm{CH}\end{array}$ \\
\hline
\end{tabular}

*) and other depending on the used narrow band filter in the range of the light wave of 179-800 nm/także inne w zależności od zastosowanego filtra waskopasmowego w zakresie dlugości fali świetlnej 179-800 nm

The RCM is controlled by a computer device - sequencer generating individual signals to the actuators (electromagnetic valves), Fig. 3. This enables the control and adjustment of the individual elements of the research system: opening of the control air intake and exhaust (under the piston), opening of the intake and exhaust valve of the working air, injectors control (gasoline or diesel fuel), discharge of the electric impulse on the spark plug and the initiation of the image recording process. The system can operate in 16 channels with the resolution of $\pm 1 \mathrm{~ns}$.

The RCM test stand was equipped with an ignition system (spark ignition cycle version), fuel air and cylinder heating systems as well as sensors: fed air pressure sensor, fed fuel pressure sensor, working area pressure sensor, piston travel sensor, cylinder temperature sensor, fed air temperature sensor etc. rys. 3. Pozwala on na wysterowanie pracą poszczególnych elementów układu badawczego: otwarciem dolotu i otwarciem wylotu powietrza sterującego (pod tłok), otwarciem zaworu dolotu i otwarciem wylotu powietrza roboczego, sterowaniem wtryskiwaczem lub wtryskiwaczami paliwa (benzyny oraz oleju napędowego), wyzwoleniem impulsu elektrycznego na świecy zapłonowej i początkiem procesu filmowania. Układ pozwala na sterowanie w 16 kanałach z rozdzielczością \pm 1 ns.

Stanowisko RCM wyposażone zostało w układ zapłonowy (w wersji dla cyklu ZI), układ podgrzewania paliwa, powietrza oraz cylindra, a także w czujniki pomiarowe: ciśnienia powietrza zasilającego, ciśnienia paliwa zasilającego, ciśnienia w przestrzeni roboczej, drogi łłoka, temperatury cylindra, temperatury powietrza zasilającego, itp. 


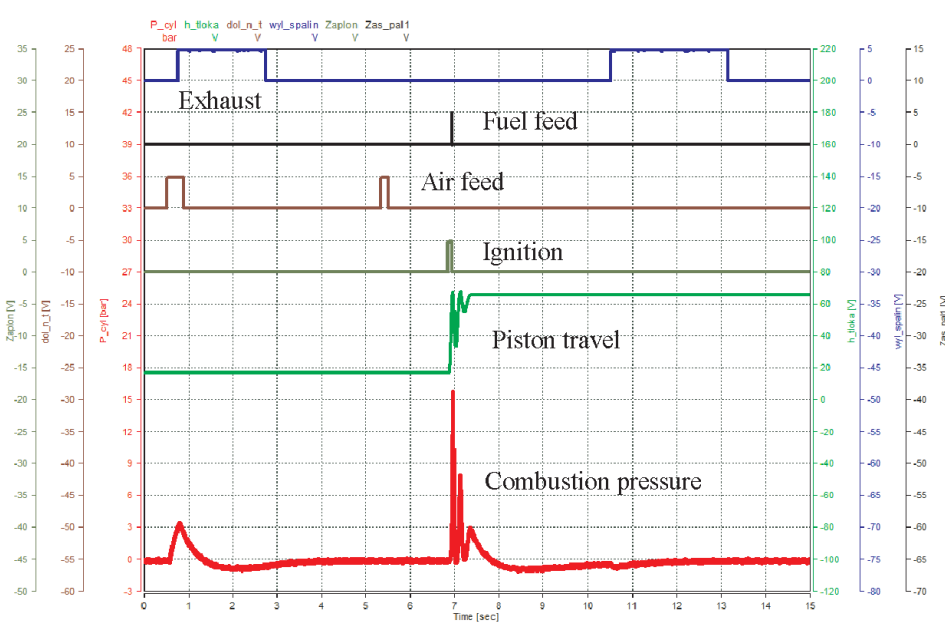

Fig. 3. Parameters recorded during the machine operating cycle (quantities forcing the piston motion and those resulting from the combustion)

Rys. 3. Parametry rejestrowane podczas cyklu pracy maszyny (wielkości wymuszajace ruch tłoka oraz wynikajace ze spalania)

RCM can be fueled with spark ignited fuels (gasoline, ethanol, methanol and their mixtures) and diesel fuel (or alternative fuels - fatty acid methyl esters - popular B100 or their mixtures). Gasoline fuel is supplied with a direct injection system. The system allows pressure adjustment in the range of 5-30 MPa. A high-pressure pump used in BMW engines and an outward-opening injector were applied in the system $[8,13]$. The fuel injection can be realized through two injectors with any number of fuel doses. The minimum injection duration is $200 \mu \mathrm{s}$, the minimum dwell time between the doses is $150 \mu \mathrm{s}$ (at $4000 \mathrm{rpm}$ which corresponds to approximately $0.006{ }^{\circ} \mathrm{C}$.A.).

The machine in the diesel cycle is powered through a common rail system that allows a free adjustment of the fuel pressure in the range of 30-140 MPa. In both cases (gasoline and diesel engines) it is possible to use high-pressure electromagnetic and piezoelectric injectors (maximum two injectors operating at the same time).

The application of a modified piston ring and a modified head allows investigations of the injection with the use of two opposite placed injectors and a centrally located spark plug (which was achieved by applying a long electrode plug-used in the gas combustion systems). These processes are currently very poorly explored and remain chiefly in the realm of computer simulation. The specific cylinder head solution allows a varied location of the spark plug and the injectors and at the same time allows optical access to the working area, thus enabling the recording and subsequent analysis of the occurring phenomena.

\section{Thermodynamic investigations of the combus- tion processes}

The thermodynamic investigations are chiefly related to the injection and combustion of fuel, particularly to the processes of:

a) The change of the compression pressure as a result of the geometrical parameters of the system (discussed earlier)
RCM może być zasilana zarówno paliwem wykorzystywanym do silników o zapłonie iskrowym (benzyna, etanol, metanol i ich mieszaniny) jak i olejem napędowym (lub także paliwami alternatywnymi - estrami metylowymi kwasów tłuszczowych - popularnego B100 lub ich mieszaninami). Paliwo benzynowe dostarczane jest zbudowanym układem wtryskowym wykorzystującym wtrysk bezpośredni. Układ pozwala na stosowanie ciśnienia wtrysku w zakresie 5-30 MPa. Zastosowano pompę wysokociśnieniową stosowaną w silnikach firmy BMW oraz wtryskiwacz typu outwardopening [8, 13]. Możliwa jest realizacja wtrysku paliwa dwoma wtryskiwaczami z dowolną liczbą dawek wtryskiwanego paliwa. Minimalny czas wtrysku wynosi $200 \mu$ s, minimalna odległość czasowa między wtryskiwanymi dawkami paliwa wynosi $150 \mu \mathrm{s}$ (przy $4000 \mathrm{obr} / \mathrm{min}$ odpowiada to ok. 0,006 $\left.{ }^{\circ} \mathrm{OWK}\right)$.

Zasilanie maszyny pracującej w cyklu silnika o zapłonie samoczynnym realizowane jest przez układ common rail pozwalający na dowolne sterowanie wartością ciśnienia paliwa w zakresie $30-140 \mathrm{MPa}$. W obu przypadkach silników ZI oraz ZS możliwe jest wykorzystanie wysokociśnieniowych wtryskiwaczy elektromagnetycznych oraz piezoelektrycznych (maksymalnie dwa wtryskiwacze pracujące jednocześnie).

Zastosowanie zmodyfikowanego pierścienia cylindrowego oraz głowicy pozwala na badania procesu wtrysku i spalania z zastosowaniem dwóch przeciwsobnie umieszczonych wtryskiwaczy i centralnie umieszczonej świecy zapłonowej (co osiągnięto przez zastosowanie świecy o długiej części elektrodowej - stosowanej w układach spalania gazu). Procesy te są obecnie bardzo słabo rozpoznane i pozostają głównie w fazie symulacji komputerowej. Specyficzne rozwiązanie głowicy pozwala na różne wzajemne usytuowanie świecy oraz wtryskiwaczy a jednocześnie umożliwia dostęp optyczny do przestrzeni roboczej, pozwalając na rejestrację i późniejszą analizę zachodzących zjawisk.

\section{Badania termodynamiczne procesów spalania}

Badania termodynamiczne związane są głównie z wtryskiem i spalaniem paliwa, a szczególnie dotyczą następujących procesów:

a) zmian ciśnienia sprężania $w$ wyniku zmian parametrów geometrycznych układu (o których była mowa wcześniej) oraz warunków termodynamicznych (głównie temperatury dolotu powietrza oraz paliwa, temperatury ścianek układu tłokowo-cylindrowego),

b) zmian ciśnienia spalania oraz jego przebiegu w wyniku sterowania procesem wtrysku i spalania - przykład zarejestrowanych przebiegów pokazano na rys. 4.

Maszyna Pojedynczego Cyklu musi spełniać określone warunki, aby możliwe było prowadzenie badań spalania paliwa. Jakość odwzorowania warunków silnikowych określono przez wyznaczenie wartości stopnia sprężania (przedstawionego w tab. 1) oraz wykładnika politropy sprężania. Wykładnik ten w warunkach zimnego rozruchu silnika wynosi 1,265. 
and the thermodynamic parameters (mainly temperature of the intake air and fuel, temperature of the cylinder walls),

b) Changes and course of the combustion pressure as a result of the control of the injection and combustion processes - an example of the recorded courses have been shown in Fig. 4.

A rapid compression machine must meet certain conditions in order for engineers to carry out investigations on fuel combustion. The accuracy of the reflection of the engine conditions was assessed through determining of the compression ratio (as shown in Table 1) and the compression politropic exponent. This exponent under the conditions of engine cold start amounts to 1.265.

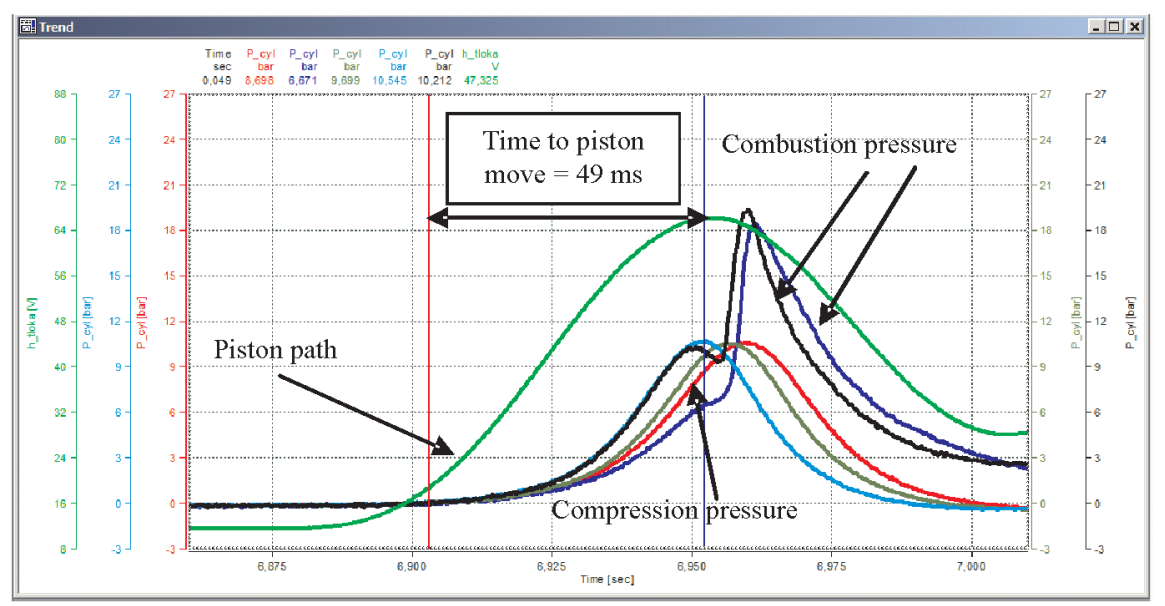

Fig. 4. The course of the compression and combustion pressure depending on the values of the pressure forcing the motion of the piston (in the case of the spark ignition cycle)

Rys. 4. Przebieg ciśnienia sprężania i spalania w zależności od różnych wartości ciśnienia wymuszajacego ruch tłoka (w przypadku silnika o zapłonie iskrowym)

The engine cold start results form the fact that the piston and the cylinder are not heated. This results in the cylinder blowby's as the piston rings are not yet tight enough.

Another parameter is the value of the temperature of the end of compression, which in the case of gasoline engine is a decisive parameter in terms of combustion. In an engine using homogenous mixtures (multipoint injection into the intake manifold) the temperature influences the rate of fuel evaporation and the quality of the obtained combustible mixture). In a gasoline direct injection engine the ignition occurs during the injection of the initial fuel dose onto the spark plug. The air temperature inside the cylinder does not directly influence the quality of the formed mixture.

The way the compression politropic exponent $\kappa$ is calculated and the temperature of the end of compression in the case of a spark ignition engine has been shown in Fig. 5. These parameters for spark ignition and diesel engines have been shown in Table 3. Based on the said table it is possible to calculate the following thermodynamic quantities of the process (single dimensional model of heat release) in individual points of the process duration:

a) The intensity of the fuel outflow from the injector (depending on the backpressure in the cylinder),

b) The value of the ignition and self ignition delay,

c) Average temperature of the compression and combustion of the charge,

d)Rate of pressure increment after the ignition,
Zimny rozruch silnika wynika $\mathrm{z}$ braku podgrzewania tłoka i cylindra. Powoduje to nieszczelności cylindra w wyniku rozszerzalności pierścieni tłokowych i tłoka.

Kolejnym parametrem jest wartość temperatury końca sprężania, która w przypadku silnika o zapłonie iskrowym nie jest parametrem decydującym o procesie spalania. W silniku wykorzystującym mieszanki jednorodne (typu wtrysku wielopunktowego do kolektora dolotowego) temperatura ta ma wpływ na szybkość odparowania paliwa i jakość uzyskanej mieszanki palnej). W silniku o wtrysku bezpośrednim benzyny zapłon następuje podczas wtrysku początkowej dawki na świecę zapłonową. Temperatura powietrza wewnątrz cylindra nie oddziałuje bezpośrednio na jakość tworzonej mieszanki palnej.

Sposób obliczania wykładnika politropy sprężania $\kappa$ oraz temperatury końca sprężania w przypadku silnika o zapłonie iskrowym przedstawiono na rys. 5. Zestawienie

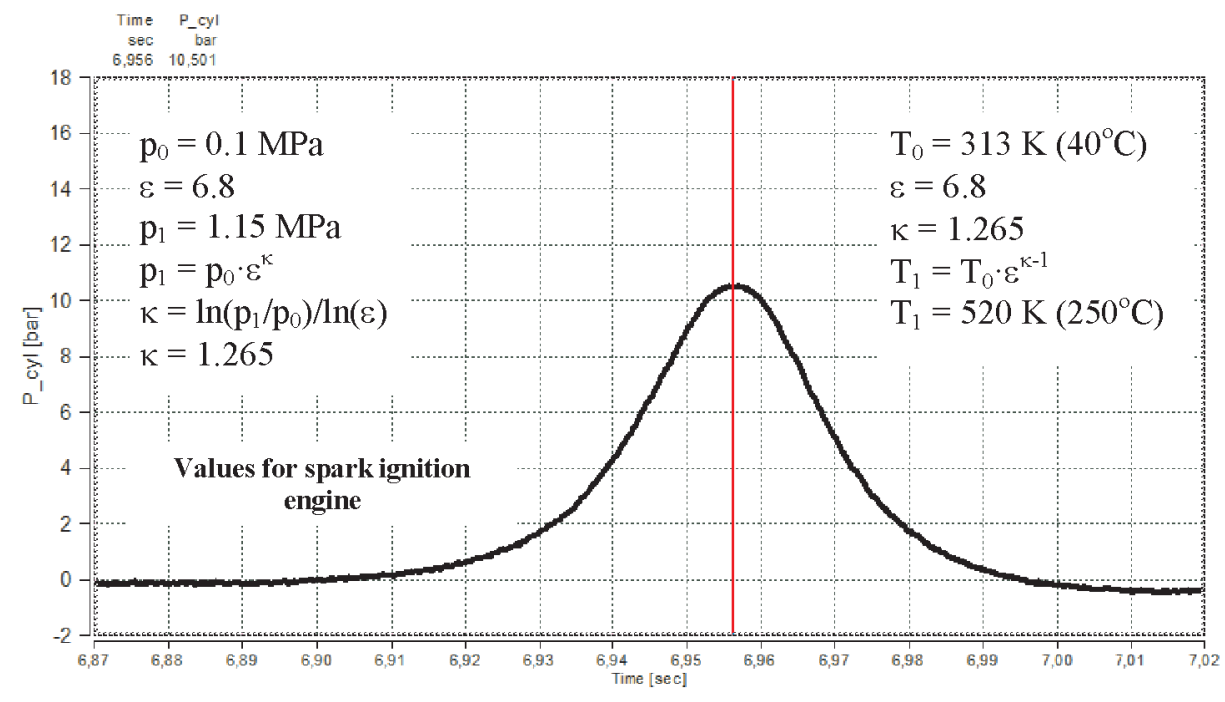

Fig. 5. The thermodynamic quantities based on the example of a process realized for a gasoline engine Rys. 5. Wielkości termodynamiczne na przykładzie procesu realizowanego dla silnika ZI 
e) The rate of heat release, amount of heat released,

f) The level of fuel feed during combustion.

Table 3. Rapid compression machine thermodynamic parameters Tablica 3. Parametry termodynamiczne maszyny pojedynczego cyklu

\begin{tabular}{|l|c|c|}
\hline Quantity/ Wielkość & $\begin{array}{c}\text { Gasoline engine/ } \\
\text { silnik ZI }\end{array}$ & $\begin{array}{c}\text { Diesel engine/ } \\
\text { silnik ZS }\end{array}$ \\
\hline $\begin{array}{l}\text { Politropic exponent of the com- } \\
\text { pression } \kappa / \text { wyktadnik politropy } \\
\text { sprężania } \kappa\end{array}$ & 1.265 & 1.265 \\
\hline $\begin{array}{l}\text { Temperature at the end of } \\
\text { compression/temperatura końca } \\
\text { sprężania }\end{array}$ & $\begin{array}{c}\text { Approx. } 480 \mathrm{~K} \\
\left(205^{\circ} \mathrm{C}\right)\end{array}$ & $\begin{array}{c}\text { Approx. } 780 \mathrm{~K} \\
\left(510^{\circ} \mathrm{C}\right)\end{array}$ \\
\hline $\begin{array}{l}\text { Pressure at the end of compres- } \\
\text { sion/ciśnienie końca sprężania }\end{array}$ & $1.05 \mathrm{MPa}$ & $4.0 \mathrm{MPa}$ \\
\hline
\end{tabular}

Having the possibility of heating the fuel we can determine the temperature influence on the quality of the atomization process, fuel spray penetration and the changes that occur in the fuel combustion - the realization of the fuel heating is possible for both gasoline (Fig. 6) and diesel fuel injection in the range of up to $250^{\circ} \mathrm{C}\left(250^{\circ} \mathrm{C}\right.$ is the boundary temperature while heating diesel fuel due to coke residue in the injector holes).

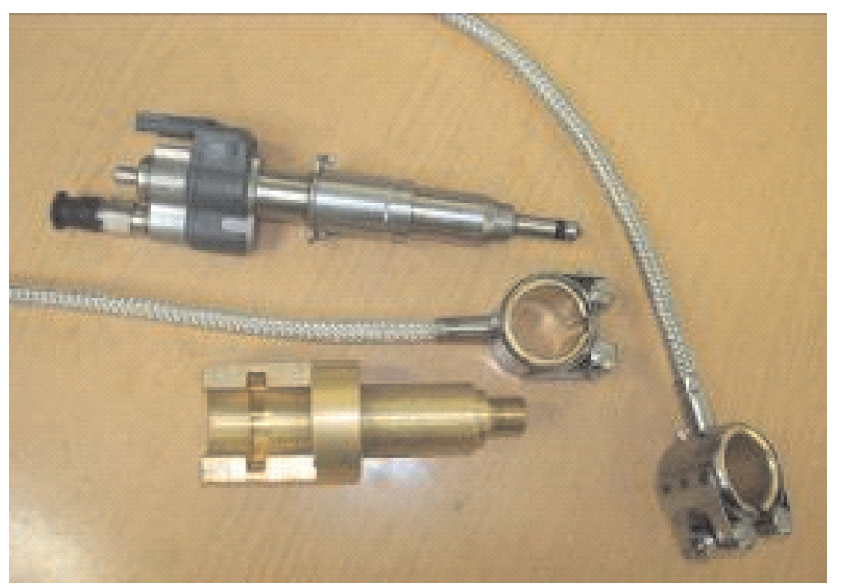

tych parametrów dla silnika ZI oraz ZS przedstawiono w tab. 3. Na tej podstawie możliwe jest obliczenie następujących wielkości termodynamicznych procesu (jednowymiarowy model wywiązywania ciepła) w poszczególnych punktach trwania procesu:

a) natężenia paliwa wypływającego z wtryskiwacza (w zależności od wartości panującego przeciwciśnienia powietrza w cylindrze),

b) wartości opóźnienia zapłonu i samozapłonu,

c) średniej temperatury procesu sprężania i spalania ładun$\mathrm{ku}$,

d) szybkości przyrostu ciśnienia po samozapłonie,

e) szybkości wywiązywania się ciepła, ilości wywiązanego ciepła,

f) stopnia wykorzystania paliwa podczas spalania.

Dysponując możliwościami podgrzewania paliwa określa się jego wpływ na jakość procesu rozpylenia, zasięg strugi oraz zmiany występujące w procesie spalania paliwa - realizacja podgrzewania paliwa możliwa jest w przypadku wtryskiwaczy benzyny (rys. 6) oraz oleju napędowego w zakresie do $250^{\circ} \mathrm{C}$ (temperatura graniczna przy podgrzewaniu oleju napędowego ze względu na koksowanie otworków wtryskiwacza).

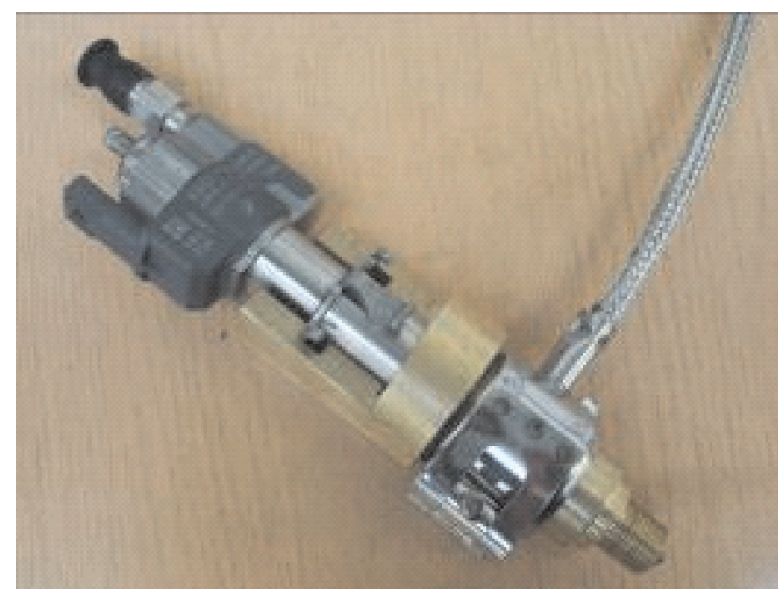

Fig. 6. The view of the gasoline injector with a heating system: a) components, b) after fitting Rys. 6. Widok wtryskiwacza benzyny z układem podgrzewania paliwa: a) elementy składowe, b) po montażu

\section{Optical investigations with the use of the system}

The possibilities of applying rapid compression machines for optical investigations are chiefly aimed at the evaluation of:

a) Course of the injection and fuel atomization,

b) Fuel spray penetration and quality of fuel atomization,

c) The duration of the electrical discharge of the spark plug,

d) Discharge temperature of the spark plug,

e) Intensity of the pre-flame processes-formation of hydrocarbon $\mathrm{CH}^{*}$ and $\mathrm{OH}^{*}$ radicals,

f) Rate of the flame front development (presented in [7]), the size of the flame area covering the combustion chamber,

\section{Badania optyczne $z$ wykorzystaniem układu}

Możliwości wykorzystania maszyny pojedynczego cyklu do badań optycznych ukierunkowane są głównie na ocenę:

a) przebiegu wtrysku i rozpylenia paliwa,

b) zasięgu strugi i jakości rozpylenia paliwa,

c) czasu wyładowania elektrycznego na świecy zapłonowej,

d) temperatury wyładowania na świecy zapłonowej,

e) intensywności przebiegu procesów przedpłomiennych - powstawania rodników węglowodorowych $\mathrm{CH}^{*}$ oraz wodorotlenowych $\mathrm{OH}^{*}$,

f) szybkości rozwoju frontu płomienia (przedstawiony m.in. w [7]), wielkości obszaru płomienia obejmującego komorę spalania, 
g) Formation of the particulate matter inside the combustion chamber.

Some of the listed investigations can be carried out simultaneously and in other cases various observations can be recorded in subsequent working cycles and relevant correlations can be sought taking into account high repeatability of the working cycles.

\section{The analysis of the recorded images}

The analysis of the recoded images is done with the use of the DaVis software by LaVision [3]. With the use of the procedures of Command Language CL the authors developed their own software that enables determining of the following quantities:

a) Fuel spray penetration, atomization quality and liquid fuel velocity coming out of the injector,

b) Evenness and quality of the injection (post injections) of liquid fuels,

c) Duration of the discharge on the spark plug,

d) Location and intensity of the radical formation during the pre-flame reactions,

e) The area occupied by the flame in the combustion chamber,

f) Distribution of the velocity vectors during the combustion of fuels (liquid and gaseous),

g) Local temperature in the combustion chamber.

An example radial fuel spray penetration has been determined as per the algorithm (Fig. 7) [14]:

a) The initial location of the center of the injector in the coordinates $\mathrm{X}$ and $\mathrm{Y}$,

b) The values of the fuel spray penetration for a single image analyzing the full angle of the fuel outflow from the injector based on its luminance,

c) The value of the average radial injected fuel dose spray penetration was determined,

a)

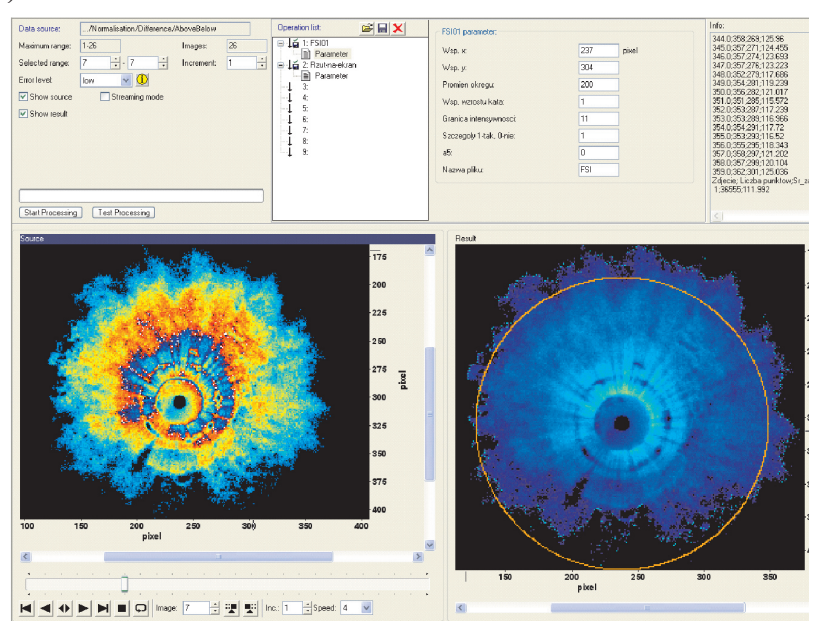

g) formowania cząstek stałych wewnątrz komory spalania.

Niektóre z wymienionych badań dają się prowadzić jednocześnie, w innych przypadkach można rejestrować różne obserwacje w kolejnych cyklach roboczych i poszukiwać odpowiednich korelacji biorąc pod uwagę uzyskiwaną dużą powtarzalność realizowanych cykli roboczych.

\section{Analiza rejestrowanych obrazów}

Analizy rejestrowanych obrazów dokonuje się z wykorzystaniem oprogramowania DaVis firmy LaVision [3]. Wykorzystując procedury języka Command Language CL opracowano własne podprogramy umożliwiające określenie następujących wielkości:

a) zasięgu strugi, jakości rozpylenia i prędkości paliw ciekłych wypływających z wtryskiwacza,

b) równomierności i jakości wtrysku (dotrysków) paliw ciekłych,

c) czasu wyładowania prądu na świecy zapłonowej,

d) miejsca i intensywności powstawania rodników podczas reakcji przedpłomiennych,

e) obszaru zajmowanego przez płomień w komorze spalania,

f) rozkładu wektorów prędkości podczas spalania paliw (ciekłych i gazowych),

g) lokalnej temperatury w komorze spalania.

Przykładowy promieniowy zasięg strugi wyznaczano według algorytmu (rys. 7) [14]:

a) określono położenie początkowe środka wtryskiwacza we współrzędnych X i Y,

b) wyznaczono wartości zasięgu strugi paliwa dla pojedynczego zdjęcia analizując pełny kąt wypływu paliwa z wtryskiwacza na podstawie jego luminancji,

c) wyznaczono wartość średniego zasięgu promieniowego dawki wtryskiwanego paliwa,

b)

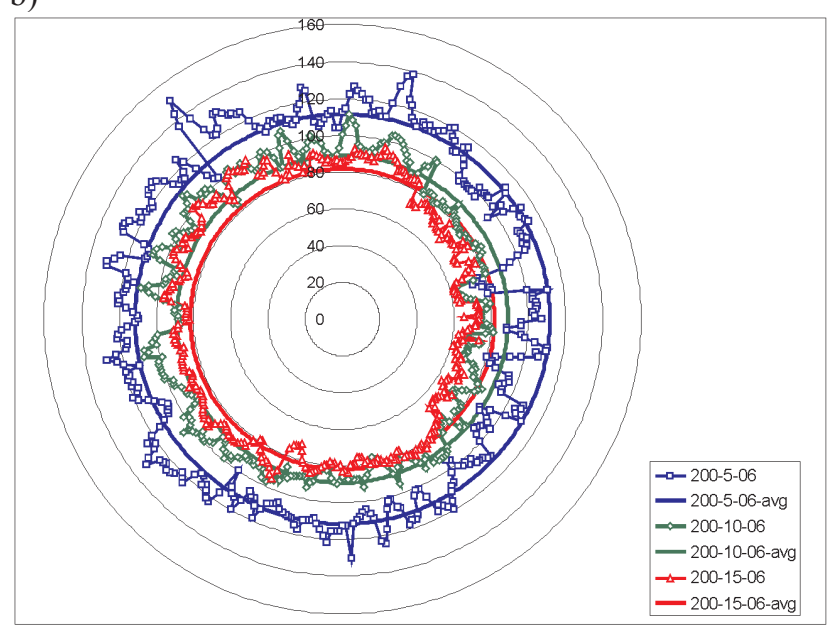

Fig. 7. The analysis of the air backpressure influence on the radial distribution of the fuel spray penetration: a) the method of determining of the radial fuel spray penetration in the DaVis software, b) the results of the applies procedures

Rys. 7. Analiza wplywu przeciwciśnienia powietrza na promieniowy rozkład zasięgu strugi wtryskiwanego paliwa: a) sposób wyznaczania promieniowego zasiegu strugi w programie DaVis, b) wyniki zastosowanych procedur 
d) Taking into account the time between the images the values of the radial displacement velocity of the fuel spray cone was determined.

The evenness of the distribution of the fuel sprays has been determined based on the following procedures:

a) The initial injector location was determined in the $X$ and Y coordinates,

b)For each recorded injection time the penetration of individual fuel sprays was determined (depending on the number of injector holes the area under analysis was divided into appropriate angular values) - a similar procedure was used in [1],

c) The fuel spray penetration was determined as a change in the assumed luminance value at the end of the individual fuel sprays (Fig. 8),

d)The average fuel spray penetration was determined as an arithmetic average of the fuel spray penetrations.

The flame front velocity was determined according to the following algorithm (Fig. 9):

a) The initial spark plug location in the $x$ and $y$ coordinates has been determined as the initial point of flame propagation;

b) The subsequent locations of the flame front were determined based on the flame luminance;

c) Taking into account the time between the images, the value of the linear velocity of the flame front displacement was determined as a boundary of the area of visible radiation with the directions and senses given.

The lengths of the vectors were graphically presented on the recorded images. Additionally, the reference lines originated in the center of the combustion chamber and joined the start and end of each of the vectors. This allows observation of the angular changes of the position of the circumferential velocity vector and determining of the angular velocity of the flame front depending on: $\omega=\Delta \varphi / \Delta \mathrm{t}$, where: $\Delta \varphi-$ denotes angular change of the flame front, $\Delta \mathrm{t}-$ time between the subsequent images.

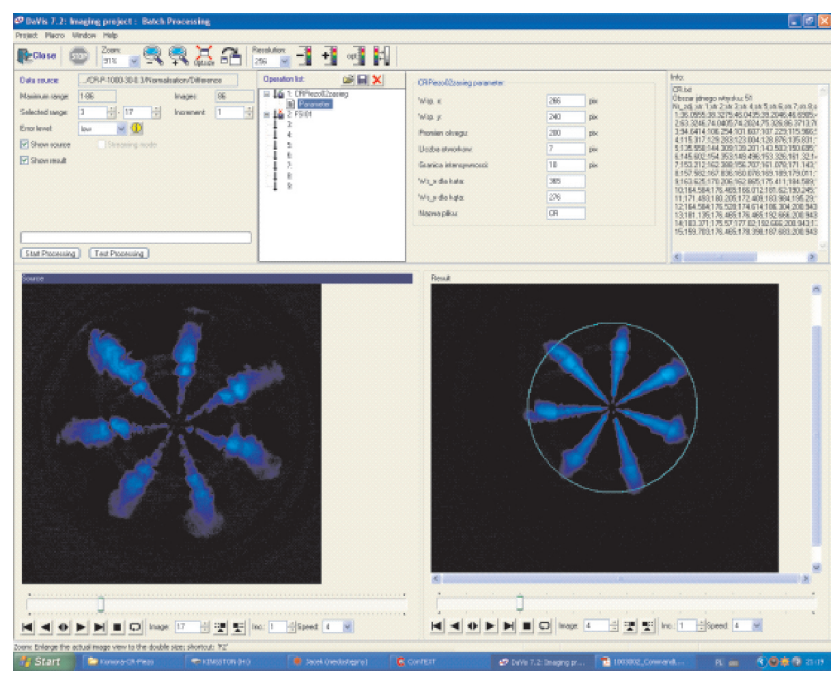

Fig. 8. The evenness of high pressure diesel fuel injection - the analysis of the image of fuel spray penetration

Rys. 8. Równomierność wtrysku wysokociśnieniowego oleju napędowego - analiza obrazu zasięgu strug wtryskiwanego paliwa d) uwzględniając czas między kolejnymi zdjęciami wyznaczono wartości promieniowej prędkości przemieszczania się czoła stożka strugi wtryskiwanego paliwa.

Równomierność rozkładu strug wtryskiwanego paliwa określano na podstawie następującej procedury:

a) określono położenie początkowe wtryskiwacza we współrzędnych X i Y,

b) dla każdego zarejestrowanego czasu wtrysku określono zasięg poszczególnych strug paliwa (w zależności od liczby otworków wtryskiwacza analizowany obszar podzielono na odpowiednie wartości kątowe) - podobną procedurę obliczeniową zastosowano w [1],

c) zasięg strug określono jako zmiana założonej wartości luminancji na końcu poszczególnych strug wtryskiwanego paliwa (rys. 8),

d) określono zasięg średni jako średnią arytmetyczną zasięgów strugi paliwa.

Prędkość frontu płomienia wyznaczano według następującego algorytmu (rys. 9):

a) określono położenie początkowe świecy we współrzędnych X i Y jako punkt początkowy rozprzestrzeniania się płomienia;

b) wyznaczono kolejne położenia frontu na podstawie luminancji płomienia;

c) uwzględniając czas między kolejnymi zdjęciami wyznaczono wektor prędkości linowej przemieszczania frontu płomienia jako granicę obszaru promieniowania widzialnego wraz z podaniem kierunku i zwrotu wektorów.

Wielkości wektorów przedstawiono w postaci graficznej na rejestrowanych obrazach. Dodatkowo zamieszczono linie odniesienia wychodzące ze środka komory spalania i łączące początek i koniec każdego z wektorów. Pozwala to na obserwację kątowych zmian położenia wektora prędkości obwodowej oraz określenie prędkości kątowej frontu płomienia z zależności: $\omega=\Delta \varphi / \Delta \mathrm{t}$, gdzie: $\Delta \varphi-$ oznacza zmianę kątową frontu płomienia, $\Delta \mathrm{t}$ - czas pomiędzy kolejnymi zdjęciami.

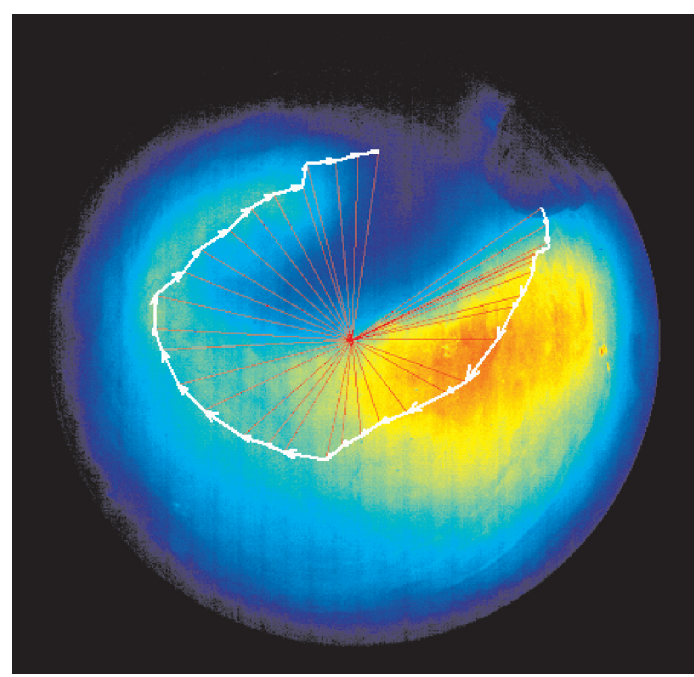

Fig. 9. The analysis of images obtained when combusting gaseous fueldistribution of velocity vectors $[2,15]$

Rys. 9. Analiza obrazów uzyskanych podczas spalania paliwa gazowego - rozkłady wektorów prędkości [2, 15] 
The distribution of temperature in the combustion chamber (Fig. 10) is possible to determine with the use of the two-color method. The two-color method of temperature determining consists in measuring of the radiation at two different light wavelengths and comparing the measured values of luminance $[4,5,9,11]$. A system of dual optics has been used where two optical filters were fitted: red (wavelength $\Lambda=700 \mathrm{~nm}$ ) and green (wavelength $\Lambda=550 \mathrm{~nm}$ ). The methodology of image processing is as follows:

a) using the law of flame emission of radiation and knowing the characteristics of the CMOS converter of the recording camera (in the range of two wavelengths $\Lambda_{1}$ i $\Lambda_{2}$ ) the temperature was determined $[10,12]$ in a given point of the image in the $\mathrm{x}, \mathrm{y}$ coordinates,

a)

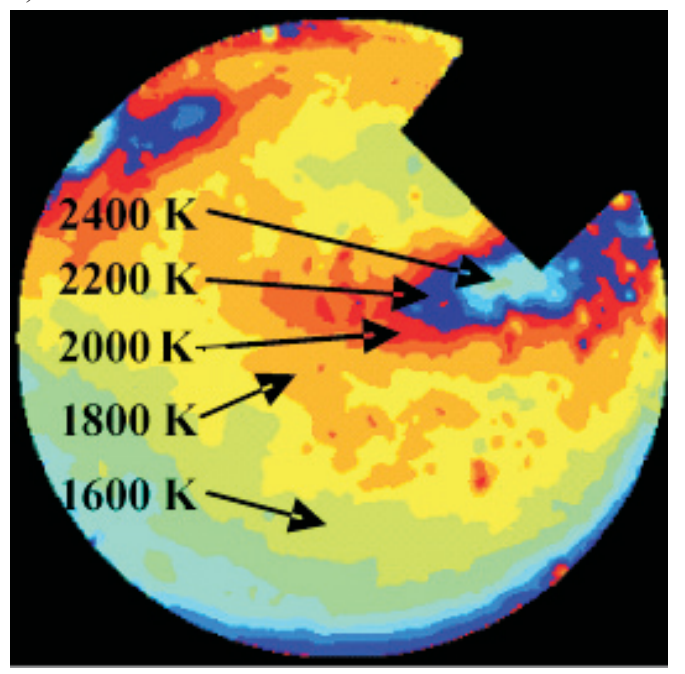

b)
Rozkład temperatury w komorze spalania (rys. 10) możliwy jest do określenia $\mathrm{z}$ wykorzystaniem metody dwubarwowej. Dwubarwowa metoda wyznaczania temperatury promiennika polega na pomiarach promieniowania przy dwóch różnych długościach fal świetlnych i porównania zmierzonych wartości luminancji $[4,5,9,11]$. Zastosowano układ podwójnej optyki, w którym zamontowano dwa filtry optyczne: czerwony (o długości fali $\Lambda=700 \mathrm{~nm}$ ) i zielony (o długości fali $\Lambda=550 \mathrm{~nm}$ ). Metodyka obróbki obrazów jest następująca:

a) wykorzystując prawo dotyczące emisyjności promieniowania płomienia oraz znając charakterystykę przetwornika CMOS kamery rejestrującej obrazy (w zakresie dwóch długości fal $\Lambda_{1}$ i $\Lambda_{1}$ ) wyznaczono temperaturę $[10,12] \mathrm{w}$ danym punkcie obrazu o współrzędnych $(\mathrm{x}, \mathrm{y})$,

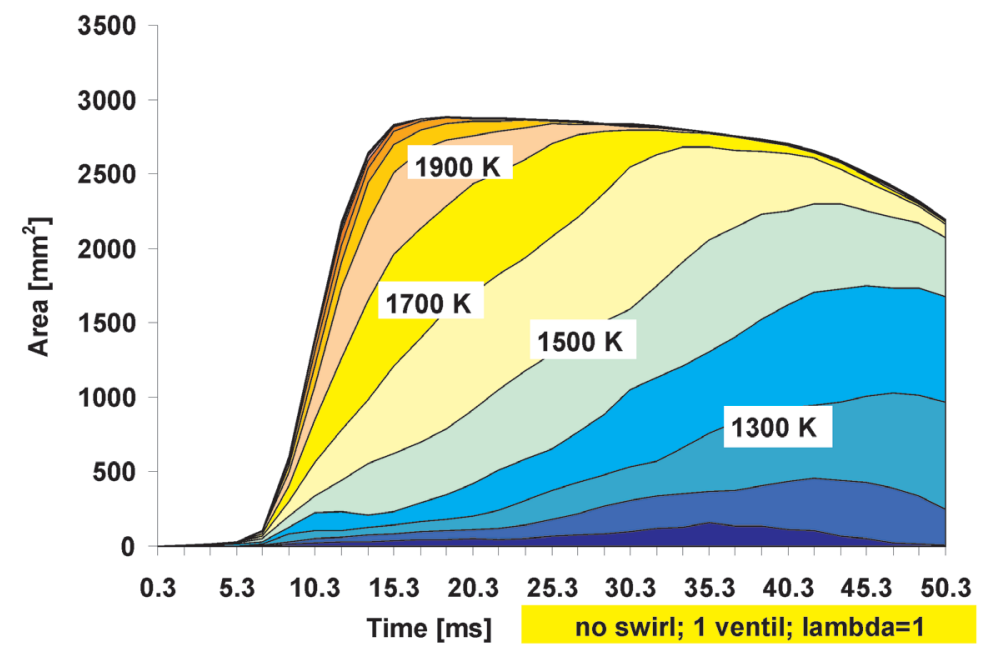

Fig. 10. Determining of the temperature distribution in the combustion chamber: a) calculating of the temperature distribution in the combustion chamber, b) changes in the temperature in the function of time in the combustion chamber [2, 15]

Rys. 10. Określenie rozkładu temperatury w komorze spalania: a) wyznaczenie rozkładu temperatury w komorze spalania, b) zmiany rozkładu temperatury $w$ czasie $w$ komorze spalania $[2,15]$

b)The analysis of all the points of the image allows presenting a distribution of the temperature in the combustion chamber during the whole process.

System-based investigations performed with the use of a Rapid Compression Machine require using of the following devices:

a) Quick changing processes data acquisition system - AVL IndiCom 621 the enables the measurement of indicator signals with an appropriate time resolution,

b) Image recording system DaVis with a high-speed camera High Speed Star 5 by LaVision.

The authors have developed software that allows time synchronization of the recorded quick changing signals with the use of the HSS5 camera. The result of these works is the possibility of a detailed evaluation of the in-engine processes with a simultaneous access to the physical values of the process (course of combustion pressure, the location of the discharge on the spark plug and the like) - Fig. 11. b) analiza wszystkich punktów obrazu pozwala na przedstawienie rozkładu temperatury w komorze spalania podczas całego procesu.

Systemowe badania procesu spalania wykonywane $\mathrm{z}$ wykorzystaniem maszyny pojedynczego cyklu wymagają zastosowania następującej aparatury:

a) systemu do akwizycji procesów szybkozmiennych AVL IndiCom 621, pozwalającego na zapis sygnałów indykatorowych z odpowiednią rozdzielczością czasową sygnałów,

b) systemu do rejestracji zdjęć DaVis wraz z kamerą do szybkich zdjęć High Speed Star 5 firmy LaVision.

Opracowano oprogramowanie pozwalające na uzyskanie synchronizacji czasowej rejestrowanych sygnałów szybkozmiennych oraz rejestrowanych obrazów za pomocą kamery HSS5. Rezultatem tych prac jest możliwość dokładnej oceny procesów wewnątrzsilnikowych z jednoczesnym ,„podglądem" wartości fizycznych procesu (przebiegu ciśnienia 
a)

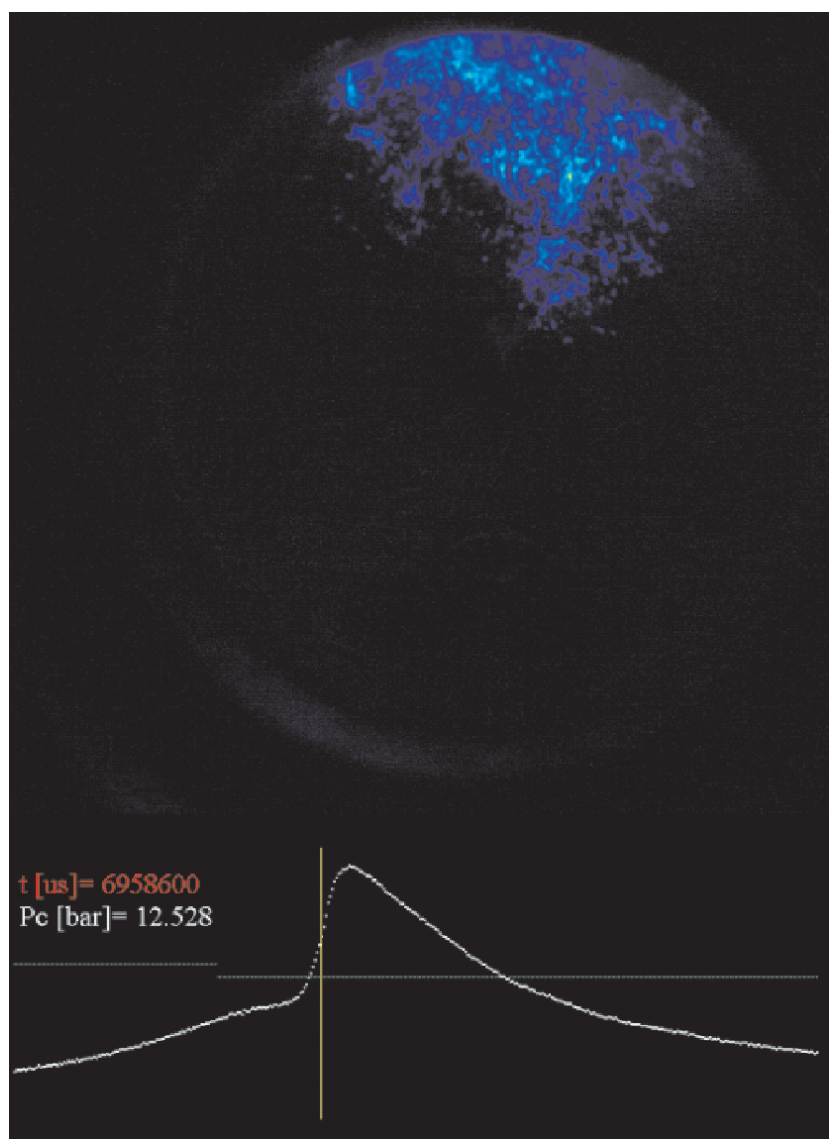

b)

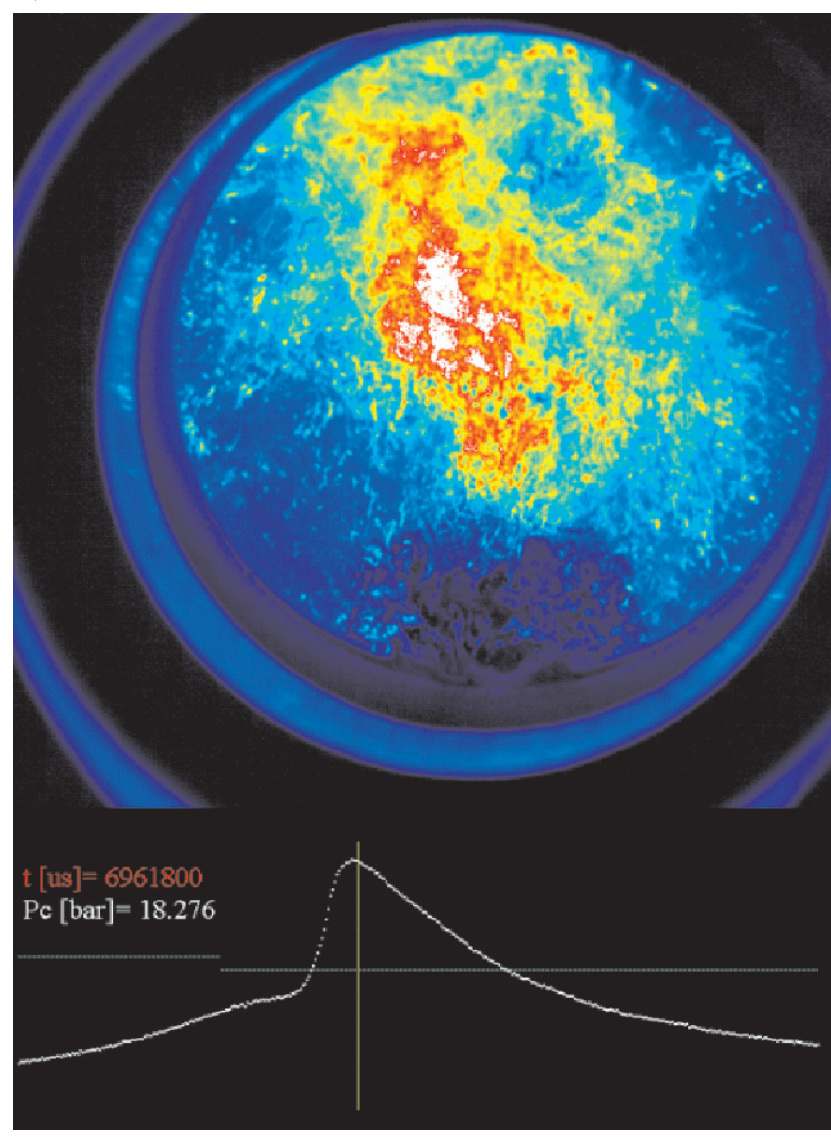

Fig. 11. The synchronization of the images with the course of the quick changing values: a) the image of pressure after the ignition, b) the image corresponding to the maximum combustion pressure

Rys. 11. Synchronizacja obrazów wraz z przebiegiem wartości szybkozmiennych: a) obraz ciśnienia po zaptonie, b) obraz odpowiadajacy maksymalnетu ciśnieniu spalania

\section{Conclusions}

The use of a rapid compression machine allows a more thorough exploration of the basic processes which is particularly influenced by:

a) The possibility of controlling of the air intake process; the possibility of supercharging at any piston position,

b) The possibility of a full control over the character and process of the injection (type of fuel, fuel injection pressure, fuel dose division, injection time),

c) The measurement of the exhaust emissions from a single operating cycle.

The above possibilities not only allow the control of the process of injection, but also the process of combustion in the presented system, which extends its possibilities of application and at the same time complies to the ever changing requirements of the current trends in the development of combustion engines. Such investigations can be performed in a much shorter time at much lower costs.

Paper reviewed/Artykut recenzowany spalania, miejsca wystąpienia wyładowania na świecy zapłonowe i innych) - rys. 11 .

\section{Zakończenie}

Wykorzystanie maszyny pojedynczego cyklu pozwala na pełniejsze poznanie procesów podstawowych, na co szczególnie ma wpływ:

a) możliwość sterowania procesem dolotu powietrza; wykorzystanie możliwości doładowania cylindra powietrzem w dowolnym położeniu tłoka,

b) możliwość pełnego sterowania sposobem i procesem wtrysku paliwa (rodzaj paliwa, wartość ciśnienia wtryskiwanego paliwa, podział dawki paliwa, czas wtrysku),

c) pomiar emisji spalin składników gazowych z jednego cyklu pracy.

Powyższe możliwości pozwalają na sterowanie procesem wtrysku, ale również i spalania w prezentowanym układzie, co zwiększa możliwości jego zastosowania i jednocześnie dostosowania do zmiennych wymagań obecnych kierunków rozwoju silników spalinowych. Badania takie mogą być przeprowadzone w zdecydowanie krótszym czasie przy zdecydowanie niższym nakładzie kosztów. 


\section{Acknowledgments}

This work has been sponsored by the Polish Ministry of Science an Higher Education as a research project No NN 502088438 in the years 2010-2012.

\section{Źródlo finansowania}

Prezentowana praca została wykonana $\mathrm{w}$ ramach projektu badawczego nr NN 502088438 finansowanego przez Ministerstwo Nauki i Szkolnictwa Wyższego w latach 2010-2012.

\section{Bibliography/Bibliografia}

[1] Andersson Ö, Horn U, Persson H, Egnell R., Rijk E.: The Influence of Fuel Properties on Transient Liquid-Phase Spray Geometry and on CI-Combustion Characteristics, SAE Technical Paper 2009-01-2774.

[2] Czajka J.: Doświadczalna ocena powstawania i rozprzestrzeniania się płomienia $\mathrm{w}$ przestrzeni zamkniętej w silnie zawirowanym ośrodku. Rozprawa doktorska. Politechnika Poznańska, 2010.

[3] Davis 7.2. LaVision, Göttingen, Niemcy. www.lavision.de

[4] Gill K., Zhao H.: In-cylinder Studies of Fuel Injection and Combustion from a Narrow Cone Fuel Injector in a High Speed Single Cylinder Optical Engine. SAE Technical Paper 2008-01-1789.

[5] Guibert P., Keromnes A., Legros., G.: Development of a Turbulence Controlled Rapid Compression Machine for HCCI Combustion. SAE Technical Paper 2007-01-1869.

[6] Jiang F., i in.: Experimental study on measurement of flame temperature distribution using the two-color method. Journal of Thermal Science, Vol. 11, Nr 4, 2002.

[7] Landry L., Halter F., Foucher F., Samson E., MounaïmRousselle C.: Effect of Pressure and Dilution on Flame Front Displacement in Boosted Spark-Ignition Engine Combustion. SAE Technical Paper 2008-01-1625.

Prof. Krzysztof Wisłocki, DSc, DEng. - Professor at the Faculty of Working Machines and Transportation of Poznan University of Technology.

Prof. nzw. dr hab. inż. Krzysztof Wistocki - Profesor nzw. na Wydziale Maszyn Roboczych i Transportu Politechniki Poznańskiej.

e-mail: krzysztof.wislocki@put.poznan.pl

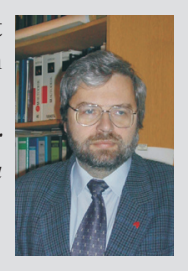

Mr. Ireneusz Pielecha, DEng. - doctor at the Faculty of Working Machines and Transportation of Poznan University of Technology.

Dr inż. Ireneusz Pielecha - adiunkt na Wydziale Maszyn Roboczych i Transportu Politechniki Poznańskiej. e-mail: ireneusz.pielecha@put.poznan.pl

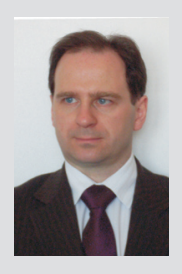

Mr. Dmitrij Maslennikov, MEng. - post-graduated student at the Faculty of Working Machines and Transportation of Poznan University of Technology.

Mgr inż. Dmitrij Maslennikov - doktorant na Wydziale Maszyn Roboczych i Transportu Politechniki Poznańskiej.

e-mail:dmytro.maslennikov@put.poznan.pl
[8] Lohfink C., Baecker H., Tichy M.: Experimental Investigation on Catalyst-Heating Strategies and Potential of GDI Combustion Systems. SAE Technical Paper 2008-01-2517.

[9] Musculus M., Singh S., Reitz R.D.: Gradient effects on twocolor soot optical pyrometry in a heavy-duty DI diesel engine. Combustion and Flame 153 (2008).

[10] Pastor J.V., García J.M., Pastor J.M., Buitrago J.E.: Analysis Methodology of Diesel Combustion by Using Flame Luminosity, Two-Colour Method and Laser-Induced Incandescence. SAE Technical Paper 2005-24-012.

[11] Stumpf M., Velji A., Spicher U., Jungfleisch B., Suntz R., Bockhorn H.: Investigations on Soot Emission Behavior of A Common-Rail Diesel Engine during Steady and Non-Steady Operating Conditions by Means of Several Measuring Techniques. SAE Technical Paper 2005-01-2154.

[12] Svensson K.I., Mackrory A.J., Richards M.J., Tree D.R.: Calibration of an RGB, CCD Camera and Interpretation of its Two-Color Images for KL and Temperature. SAE Technical Paper 2005-01-0648.

[13] Schwarz C., Schünemann E., Durst B., Fischer J., Witt A.: Potentials of the Spray-Guided BMW DI Combustion System. SAE Technical Paper 2008-01-1265.

[14] Wisłocki K., Pielecha I., Czajka J., Maslennikov D.: The Influence of Fuel Injection Parameters on the Indexes of Fuel Atomization Quality for a High Pressure Injection, SAE Technical Paper 2010-01-1499.

[15] Wisłocki K., Pielecha I., Czajka J., Maslennikov D.: Optical research on flame in a combustion chamber fuelled with $\mathrm{CNG}$. 8th International Symposium on High Temperature Air Combustion and Gasification HITACG, Poznan 5-7.07.2010.
Mr. Jakub Czajka, DEng. - doctor at the Faculty of Machines and Transportation of Poznan University of Technology.

Dr inż. Jakub Czajka - adiunkt na Wydziale Maszyn Roboczych i Transportu Politechniki Poznańskiej. e-mail: jakub.czajka@put.poznan.pl
Mr. Jacek Kaźmierowski, MEng. - post-graduated student at the Faculty of Working Machines and Transportation of Poznan University of Technology.

Mgr inż. Jacek Kaźmierowski - inspektor Urzędu Dozoru Technicznego, doktorant na Wydziale Maszyn Roboczych i Transportu Politechniki Poznańskiej. e-mail: jacekkazmierowski@udt.gov.pl
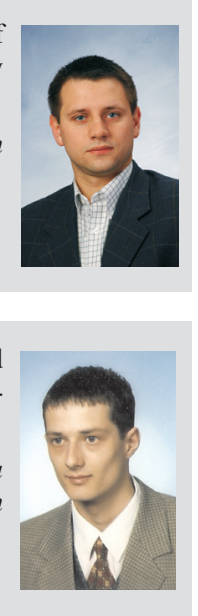